
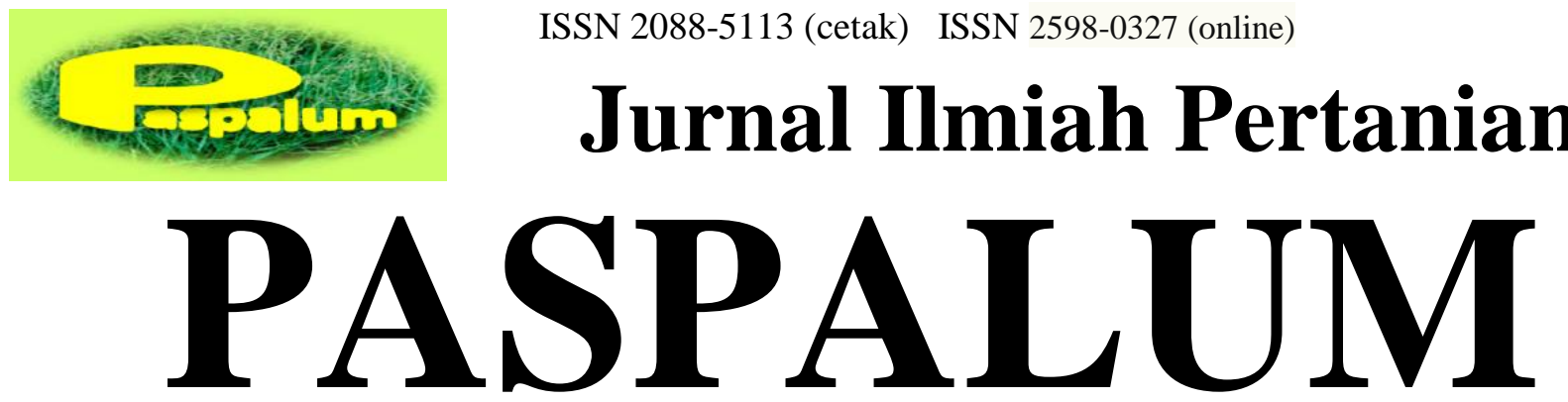

Volume. 6 No. 1 Bulan Maret Tahun 2018

http://journal.unwim.ac.id/index.php/paspalum

\title{
Respons Tanaman Jagung (Zea mays L.) Hibrida Akibat Jarak Tanam Berbeda Pada Sistem Tatam Legowo (2:1) Dan Jenis Pupuk Organik Di Inceptisols Jatinangor.
}

\author{
A. Wahyudin, Y. Yuwariah, F. Yulianto W., A. F. Kevin A \\ Departemen Budidaya Pertanian Fakultas Pertanian Unpad \\ agus.wahyudin@unpad.ac.id
}

Diterima tgl : 15-02-2018 dan disetujui untuk diterbitkan tgl : 31-03-2018

\begin{abstract}
The objective of this research was to find the best combination of plant spacing and organic fertilizer on the growth and yield of maize (Zea mays L.) Pertiwi-3 in Jatinangor. The experiment was carried outin Ciparanje experimental field on November 2016 to March 2017. The experiment used was Randomized Block Design (RBD) which consisted of six treatments and four replications, which were the plant spacing $20 \mathrm{~cm} \times 20 \times m \times 75 \mathrm{~cm}+5 \mathrm{t} /$ ha compost, $25 \mathrm{~cm} \times 25 \mathrm{~cm} \times 75 \mathrm{~cm}+5 \mathrm{t} /$ ha compost, $30 \mathrm{~cm} \times 30 \mathrm{~cm} \times 75 \mathrm{~cm}+5 \mathrm{t} /$ ha compost, $20 \mathrm{~cm} \times 20 \mathrm{~cm} \times 75 \mathrm{~cm}+5 \mathrm{t} /$ ha cow manure, $25 \mathrm{~cm} \times 25 \mathrm{~cm} \times 75 \mathrm{~cm}+5 \mathrm{t} / \mathrm{ha}$ cow manure and $30 \mathrm{~cm} \times 30 \mathrm{~cm} \times 75 \mathrm{~cm}+5 \mathrm{t} / \mathrm{ha}$ cow manure. The result of the experiment showed that the best result of 100 dry seeds weight was in the treatment of plant spacing $20 \mathrm{~cm} \times 20 \mathrm{~cm} \times 75 \mathrm{~cm}+5 \mathrm{t} / \mathrm{ha}$ cow manure with a weight of $45,19 \mathrm{~g}$. The highest score of Leaf Area Index (LAI) was in the treatment of plant spacing $20 \mathrm{~cm} x 20 \mathrm{~cm} \times 75 \mathrm{~cm}+5 \mathrm{t} / \mathrm{ha}$ cow manure score of 2,92 was not significantly different from the treatment of plant spacing $20 \mathrm{~cm} x 20 \mathrm{~cm} \times 75 \mathrm{~cm}+5 \mathrm{t} / \mathrm{ha}$ compost with score of 2,82 .
\end{abstract}

Keywords: corn, double row, organic fertilizer.

\begin{abstract}
Abstrak
Penelitian ini bertujuan untuk memperoleh jarak tanam dan jenis pupuk organik terbaik terhadap pertumbuhan dan hasil tanaman jagung (Zea mays L.) Pertiwi-3 di Jatinangor. Penelitian dilaksanakan di kebun percobaan Ciparanje Fakultas Pertanian Universitas Padjadjaran, pada November 2016 sampai Maret 2017. Percobaan menggunakan Rancangan Acak Kelompok (RAK) dengan 6 perlakuan dan 4 ulangan, perlakuan yang diberikan yakni jarak tanam 20cmx20xmx75cm + kompos 5t/ha, 25cmx25cmx75cm + kompos 5t/ha, $30 \mathrm{~cm} \times 30 \mathrm{~cm} \times 75 \mathrm{~cm}+$ kompos $5 \mathrm{t} / \mathrm{ha}, 20 \mathrm{~cm} \times 20 \mathrm{~cm} \times 75 \mathrm{~cm}+$ pukan sapi $5 \mathrm{t} / \mathrm{ha}, 25 \mathrm{~cm} \times 25 \mathrm{~cm} \times 75 \mathrm{~cm}+$ pukan sapi $5 \mathrm{t} /$ ha dan $30 \mathrm{~cm} \times 30 \mathrm{~cm} \times 75 \mathrm{~cm}+$ pukan sapi $5 \mathrm{t} / \mathrm{ha}$. Hasil dari perlakuan tersebut didapati bobot 100 biji pipilan kering tertinggi pada perlakuan jarak tanam $20 \mathrm{~cm} x 20 \mathrm{cmx} 75 \mathrm{~cm}+$ pukan sapi $5 \mathrm{t} /$ ha dengan bobot $45,19 \mathrm{~g}$. Nilai Indeks Luas Daun (ILD) tertinggi didapat pada perlakuan jarak tanam $20 \mathrm{~cm} x 20 \mathrm{~cm} x 75 \mathrm{~cm}+$ pukan sapi $5 \mathrm{t} / \mathrm{ha}$ dengan nilai 2,92, tidak berbeda nyata dengan perlakuan jarak tanam $20 \mathrm{cmx} 20 \mathrm{~cm} \times 75 \mathrm{~cm}+$ kompos $5 \mathrm{t} / \mathrm{ha}$ dengan nilai ILD 2,82.

Kata kunci : jagung, jajar legowo, pupuk organik.
\end{abstract}




\section{PENDAHULUAN}

Peningkatan permintaan jagung setiap tahun terus meningkat di Indonesia, hal ini disebabkan selain menjadi salah satu pangan utama di dunia termasuk di Indonesia, tanaman jagung juga digunakan sebagai bahan pakan bagi ternak dan juga sebagai bahan olahan industri. Menurut Kasryno,dkk (2007), hasil keseluruhan total produksi jagung di Indonesia lebih dari 55\% digunakan untuk kebutuhan akan pakan ternak, hanya sekitar $30 \%$ saja yang menjadi bahan konsumsi pangan, sedangkan sisanya sebagai bahan olahan pada sektor industri. Menurut data dari Badan Pusat Statistika (2015), pada beberapa daerah di Indonesia tingkat konsumsi jagung per kapita per minggu pada tahun 2014 yakni sebesar $0,23 \mathrm{~kg}$. Informasi dari Pusat Data dan Sistem Informasi Pertanian (2015), diperkirakan setiap tahun permintaan jagung untuk kebutuhan pakan akan meningkat kurang lebih 7,5\%. Seiring dengan itu data luas panen dari Badan Pusat Statistik (2016), luas panen jagung dari tahun ke tahun di Indonesia terus menurun, dari tahun 2014 sampai ke 2015 saja penurunan luas panen untuk jagung sebesar 50.204 hektar, dan diperkirakan akan terus berkurang seiring meluasnya alih fungsi lahan.

Selain masalah penyempitan lahan oleh alih fungsi, masalah pada pertanaman jagung juga disebabkan penanaman monokultur yang terus menerus. Jagung cukup banyak, namun pemberian pupuk yang banyak juga tidak berarti baik untuk tanaman dan tanah. Menurut Akil, dkk (2007) takaran unsur $\mathrm{N}$ untuk tanaman jagung pada pemupukan pertama lebih dari $150 \mathrm{~kg} / \mathrm{ha}$ adalah hal yang umum dilakukan petani. Permasalahan lain juga terdapat pada teknologi sistem budidaya. Salah satu upaya yang dapat dilakukan guna produksi jagung dapat meningkat adalah dengan cara memperbaiki sistem budidaya dengan mengatur jarak tanam, penggunaan benih dari varietas unggul dan beberapa usaha lainnya (Bunyamin dan Awaluddin, 2013).
Penggunaan jarak tanam yang tepat akan meningkatkan hasil sedangkan penggunaan jarak tanam yang tidak tepat akan menurunkan hasil (Williams and Joseph 1970 dikutip Indrayanti 2010). Menurut Stalcup (2008), penanaman sistem satu baris merupakan hal umum, untuk itu diterapkan pertanaman sistem dua baris karena mampu memberikan hasil lebih tinggi.

Faktor selanjutnya guna menyokong produksi jagung agar lebih baik yakni dari aspek asupan nutrisi atau pemupukan. Menurut Supartha et al. (2012), penggunaan pupuk anorganik mampu meningkatan produktivitas tanaman cukup tinggi, namun apabila penggunaannya dalam jangka waktu yang relatif lama dapat berakibat buruk pada kondisi tanah. Supartha et al. (2012) juga menambahkan, menekan kerugian hasil dapat dilakukan dengan cara, penggantian pupuk kimia dengan pemupukan alami, minimal satu kali dengan pupuk organik padat saat olah tanam sebagai pupuk dasar. Selain itu penggunaan pupuk organik juga bertujuan untuk mengurangi dampak residu yang ditimbulkan akibat penggunaan pupuk anorganik di dalam tanah. Menurut Dinariani, dkk (2014), penggunaan pupuk kandang dapat mengurangi biaya produksi serta meningkatkan produksi melalui perbaikan struktur tanah. Menurut Mayadewi (2007), dengan pemberian pupuk kandang dapat meningkatkan berat segar tongkol berkelobot, berat segar tongkol tanpa kelobot dan tongkol layak jual.

Pemberian pupuk kandang sapi atau kompos dengan takaran 5 ton ha $^{-1}$ dilaporkan dapat meningkatkan kadar C-organik tanah, serta meningkatkan hasil jagung dan kedelai (Adimihardja dkk, 2000). Menurut Mayadewi (2007). Pemberian pupuk organik mampu meningkatkan dan menjaga produktivitas lahan pertanian dalam jangka waktu panjang serta melestarikan sumber daya alam (Roidah dan Ida, 2013). Menurut Samosir, dkk (2015), pemberian kompos pada pertanaman jagung memberikan pengaruh yang nyata terhadap 
tinggi tanaman, jumlah daun, panjang tongkol dan bobot tongkol. Pemberian pupuk organik pada jagung sebanyak 5 ton/ha dapat menjamin ketersediaan hara secara optimum (Pusat Pelatihan Pertanian, 2015).

Menurut Bara, dkk (2009), pemberian pupuk kandang 5 ton/ha mampu meningkatkan produksi tongkol per petak sebesar 35,36\%. Menurut Subiksa (2011), kombinasi antara jarak tanam jagung $(25 \mathrm{~cm} \times 75 \mathrm{~cm})$ dan penggunaan pupuk kandang berpengaruh nyata terhadap pertumbuhan tanaman jagung di tanah Inceptisol. Penggunaan pupuk organik kotoran sapi mampu meningkatkan produksi berbagai tanaman antara $10-30 \%$ (BPTP, 2011). Menurut Mayadewi (2007), pada penanaman jagung dengan jarak tanam rapat (50 x 40) $\mathrm{cm}$ yang dikombinasikan dengan pupuk organik meningkatkan hasil tongkol layak jual sebesar $47,03 \%$. Selain itu menurut Mayadewi (2007), pemberian pupuk kandang sapi dan dengan jarak tanam lebar $(100 \mathrm{~cm} \mathrm{x}$ $20 \mathrm{~cm}$ ) menghasilkan berat tongkol berkelobot per tanaman tertinggiJarak tanam yang baik sangat bergantung pada tingkat kesuburan tanah, pengolahan lahan, pemupukan serta varietas yang ditanam (Setyamidjaja, 2006).

\section{BAHAN DAN METODE}

Percobaan dilaksanakan di Kebun Percobaan Ciparanje Fakultas Pertanian Universitas Padjadjaran, Jatinangor, Kabupaten Sumedang, Jawa Barat dengan ketinggian tempat \pm 750 meter di atas permukaan laut, tipe curah hujan C3 menurut Oldeman (1975). Waktu pelaksanaan percobaan ini yakni pada bulan November 2016 hingga Maret 2017.

Bahan yang digunakan pada percobaan ini diantaranya benih jagung hibrida varietas PERTIWI-3, urea, SP-18, KCl, pupuk kompos, pupuk kandang sapi, insektisida berbahan aktif potenotos, fungisida berbahan aktif mankozeb dan furadan berbahan aktif karbofuran. Alat yang digunakan pada percobaan ini antara lain adalah cangkul, tugal, kored, emrat atau alat penyiraman, tali rapia, meteran, pisau, seng, cat, label, plastik, jangka sorong, timbangan analitik, timbangan, oven listrik, kamera dan alat tulis.

Metode Percobaan yang digunakan adalah Rancangan Acak Kelompok (RAK), yang terdiri dari; A : Jarak Tanam $20 \mathrm{~cm}$ x $20 \mathrm{~cm}$ x $75 \mathrm{~cm}+$ kompos $5 \mathrm{t} / \mathrm{ha}$, B : Jarak Tanam $25 \mathrm{~cm} \mathrm{x}$ $25 \mathrm{~cm} \times 75 \mathrm{~cm}+$ kompos 5t/ha, C: Jarak Tanam $30 \mathrm{~cm} \times 30 \mathrm{~cm} \times 75 \mathrm{~cm}+$ kompos $5 \mathrm{t} / \mathrm{ha}, \mathrm{D}$ : Jarak Tanam $20 \mathrm{~cm} \times 20 \mathrm{~cm} \times 75 \mathrm{~cm}+$ pupuk kandang sapi $5 \mathrm{t} / \mathrm{ha}, \mathrm{E}$ : Jarak Tanam $25 \mathrm{~cm} \mathrm{x}$ $25 \mathrm{~cm} \times 75 \mathrm{~cm}+$ pupuk kandang sapi $5 \mathrm{t} / \mathrm{ha}$, F: Jarak Tanam $30 \mathrm{~cm} \times 30 \mathrm{~cm} \times 75 \mathrm{~cm}+$ pupuk kandang sapi $5 \mathrm{t} / \mathrm{ha}$.

Menurut Wahyudin, et al (2017), untuk sampel diambil $10 \%$ dari populasi tanaman per petak untuk semua perlakuan. Data pada pengamatan utama dianalisis secara statistik. Pengamatan utama meliputi pertumbuhan tanaman, komponen hasil, dan hasil tanaman jagung, yakni :

Tinggi Tanaman $(\mathrm{cm})$, Indeks Luas Daun (ILD), Panjang tongkol (cm), Diameter tongkol (cm), Jumlah biji per tongkol, Jumlah baris biji per tongkol, Bobot 100 biji (g), Bobot biji pipilan kering per tanaman (g), Bobot biji pipilan kering per hektar (t/ha) dan Indeks Panen (IP).

\section{HASIL DAN PEMBAHASAN}

Tinggi Tanaman. Pengamatan pertumbuhan tinggi tanaman dilakukan sebanyak tiga kali, yakni pada saat tanaman jagung berusia 4MST, 6MST dan 8MST. Pengukuran dilakukan dari pangkal batang yang berada di atas permukaan tanah, hingga daun terpanjang dengan bantuan alat meteran dan kayu panjang. Berdasarkan analisis sidik ragam, hasil yang diperoleh menunjukkan bahwa perlakuan yang diberikan terhadap pertanaman jagung tidak berpengaruh terhadap tinggi tanaman itu sendiri. Pengamatan pertama pada saat 4MST didapati tinggi rata-rata tanaman jagung berkisar antara 
$35,70 \mathrm{~cm}$ sampai dengan 42,78 $\mathrm{cm}$, pada pengamatan kedua (6MST) rata-rata tinggi tanaman jagung berkisar antara 79,98 cm sampai dengan $93,57 \mathrm{~cm}$ dan pada pengamatan tinggi ketiga (8MST) tinggi rata-rata tanaman jagung antara $108,00 \mathrm{~cm}$ sampai dengan $124,36 \mathrm{~cm}$.

Tabel 1. Pengaruh Perlakuan Berbagai Jarak Tanam pada Jajar Legowo dan Pemberian Pupuk Organik terhadap Tinggi Tanaman Jagung PERTIWI-3 4MST, 6MST dan 8MST.

\begin{tabular}{|c|c|c|c|}
\hline \multirow[t]{2}{*}{ Perlakuan } & \multicolumn{3}{|c|}{ Tinggi Tanaman $(\mathrm{cm})$} \\
\hline & $\begin{array}{c}4 \mathrm{MS} \\
\mathrm{T}\end{array}$ & $\begin{array}{c}6 \mathrm{MS} \\
\mathrm{T}\end{array}$ & 8MST \\
\hline $\begin{array}{l}\text { A: J1 } \\
(20 \mathrm{~cm} \times 20 \mathrm{~cm} \times 75 \mathrm{~cm} \\
)+ \text { Kompos } 5 \mathrm{tha}^{-1}\end{array}$ & $\begin{array}{c}41,68 \\
a\end{array}$ & $\begin{array}{c}92,51 \\
\mathrm{a}\end{array}$ & $\begin{array}{c}123,0 \\
1 \mathrm{a}\end{array}$ \\
\hline $\begin{array}{l}\text { B: J2 } \\
(25 \mathrm{~cm} \times 25 \mathrm{~cm} \times 75 \mathrm{~cm} \\
)+ \text { Kompos } 5 \mathrm{tha}^{-1}\end{array}$ & $\begin{array}{c}41,60 \\
\mathrm{a}\end{array}$ & $\begin{array}{c}93,57 \\
a\end{array}$ & $\begin{array}{c}124,3 \\
6 \mathrm{a}\end{array}$ \\
\hline $\begin{array}{l}\text { C: J3 } \\
(30 \mathrm{~cm} \times 30 \mathrm{~cm} \times 75 \mathrm{~cm} \\
)+ \text { Kompos } 5 \text { tha }^{-1}\end{array}$ & $\begin{array}{c}42,78 \\
a\end{array}$ & $\begin{array}{c}90,09 \\
\mathrm{a}\end{array}$ & $\begin{array}{c}116,8 \\
8 \mathrm{a}\end{array}$ \\
\hline $\begin{array}{l}\text { D: J1 } \\
(20 \mathrm{~cm} \times 20 \mathrm{cmx} 75 \mathrm{~cm} \\
{ }_{1}+\text { Pukan Sapi 5tha }\end{array}$ & $\begin{array}{c}39,33 \\
\mathrm{a}\end{array}$ & $\begin{array}{c}90,92 \\
\mathrm{a}\end{array}$ & $\begin{array}{c}118,5 \\
4 \mathrm{a}\end{array}$ \\
\hline $\begin{array}{l}\text { E: J2 } \\
(25 \mathrm{~cm} \times 25 \mathrm{cmx} 75 \mathrm{~cm} \\
)_{1}+\text { Pukan Sapi 5tha }\end{array}$ & $\begin{array}{c}41,16 \\
\mathrm{a}\end{array}$ & $\begin{array}{c}84,93 \\
a\end{array}$ & $\begin{array}{c}116,5 \\
8 \mathrm{a}\end{array}$ \\
\hline $\begin{array}{l}\text { F: J3 } \\
(30 \mathrm{cmx} 30 \mathrm{cmx} 75 \mathrm{~cm} \\
)_{1}+\text { Pukan Sapi } 5 \text { tha }\end{array}$ & $\begin{array}{c}35,70 \\
\mathrm{a}\end{array}$ & $\begin{array}{c}79,98 \\
a\end{array}$ & $\begin{array}{c}108,0 \\
0 \mathrm{a}\end{array}$ \\
\hline
\end{tabular}

Keterangan:Angka-angka pada kolom yang sama dengan notasi huruf yang sama, menunjukkan tidak berpengaruh menurut Uji F dengan taraf nyata $5 \%$.

Keseluruhan pengamatan tinggi tanaman jagung dilakukan pada saat bulan Januari 2017, menurut data dari stasiun klimatologi Ciparanje, pada bulan tersebut rata-rata penyinaran matahari yakni $46 \%$ atau kurang lebih 3,68 jam (penyinaran matahari 100\% $=8$ jam).
Penggunaan sistem tanam legowo (2:1) semakin menguntungkan bagi pertanaman dari segi penyinaran matahri, seperti yang dikemukakan oleh Misran (2014) keuntungan dari sistem tanam jajar legowo yakni menjadikan tanaman dalam sistem ini menjadi tanaman pinggir. Menurut Mujisihono dan Santosa (2001) keuntungan dari tanaman pinggir yakni memperoleh cahaya matahari lebih banyak. Pernyataan Mujisihono dan Santosa juga didukung oleh Abdulrachman, et al (2013), bahwa penggunaan sistem tanam legowo memiliki keuntungan yaitu terdapat ruang terbuka dari baris yang kosong, sehingga tanaman dapat menerima sinar matahari secara optimal yang berguna dalam proses fotosintesis. Pada awal pertumbuhan, populasi tanaman berpengaruh terhadap tinggi namun pengaruhnya akan berkurang seiring dengan bertambahnya umur tanaman, untuk jarak tanam tidak berpengaruh terhadap tinggi maksimum tanaman (Sitaniapessy, 1985 dikutip Desyanto dan Herman, 2014).

Perbandingan tinggi tanaman jagung antar perlakuan yang diberikan dapat dikatakan bahwa, pertumbuhan tinggi tanaman jagung cukup merata, dibuktikan dari hasil uji $\mathrm{F}$ yang menyatakan tidak ada pengaruh terhadap tinggi tanaman jagung di semua perlakuan yang dilakukan. Pada lahan percobaan seluruh tanaman jagung mendapatkan pencahayaan penuh, tanpa adanya naungan yang berarti. Menurut Gardner (1985) dikutip Rogi, et al (2010) cahaya matahari mempunyai pengaruh yang nyata terhadap pertumbuhan ruas. Selain itu pemberian perlakuan pupuk organik, baik kompos yang teruji memiliki kandungan unsur $\mathrm{N} 1,12 \%$ ataupun pupuk kandang sapi yang teruji mengandung unsur $\mathrm{N}$ sebanyak $0,98 \%$, ditambah pupuk urea (anorganik), serta unsur $\mathrm{N}$ total sebanyak $0,18 \%$ yang berada dalam tanah, cukup bagi tanaman jagung untuk mendukung proses pertumbuhan. Menurut Rina (2015), unsur hara N (nitrogen) dibutuhkan tanaman dalam jumlah yang banyak, karena unsur tersebut penyusun $1-5 \%$ 
dari berat tubuh tanaman, unsur $\mathrm{N}$ juga bermanfaat untuk mempercepat pertumbuhan tinggi tanaman, unsur ini diperoleh dari bahan organik, mineral tanah, maupun penambahan pupuk.

Indeks Luas Daun. Indeks Luas Daun (ILD) merupakan parameter yang menunjukkan potensi tanaman dalam melakukan fotosintesis yang secara langsung mempengaruhi pertumbuhan dan perkembangan tanaman (Wahyudin et al, 2015). Menurut uji sidik ragam, hasil yang diperoleh menunjukkan bahwa perlakuan jarak tanam dan pemberian pupuk organik baik kompos ataupun pupuk kandang sapi berpengaruh nyata terhadap indeks luas daun (ILD) tanaman jagung. Indeks luas daun yang optimum untuk menghasilkan bahan kering, berkisar antara 2,5 sampai 5, apabila melebihi maka bahan kering akan terakumulasi ke batang (Goldsorthy,1992 dikutip Tabri 2013).

Berdasarkan uji lanjut, didapati bahwa nilai indeks luas daun tertinggi terdapat pada perlakuan jarak tanam rapat $20 \mathrm{~cm} \times 20 \mathrm{~cm} \times 75 \mathrm{~cm}$ ditambah pemberian kompos dengan nilai Index Luas daun (ILD) 2,82 dan perlakuan jarak tanam rapat $20 \mathrm{~cm} \times 20 \mathrm{~cm} \times 75 \mathrm{~cm}$ ditambah pupuk kandang sapi dengan nilai ILD 2,92, serta tidak berbeda nyata juga terhadap hasil indeks luas daun pada perlakuan jarak tanam $25 \mathrm{~cm} x 25 \mathrm{~cm} \times 75 \mathrm{~cm}$ yang ditambah kompos dengan nilai indeks luas daun 2,52.

Nilai indeks luas daun hasil uji lanjut didapati yang terendah pada perlakuan jarak tanam lebar $30 \mathrm{~cm} \times 30 \mathrm{~cm} \times 75 \mathrm{~cm}$ ditambah pemberian kompos dengan nilai ILD 1,84, tidak berbeda nyata dengan perlakuan jarak tanam 30cmx30cmx75cm ditambah pupuk kandang sapi dengan nilai ILD 1,95. Menurut Jugerheimer (1976) dikutip Sumarsono (2008), kepadatan populasi tanaman yang tinggi akan meningkatkan indeks luas daun (ILD). Menurut Sari, dkk (2016), pupuk juga berperan sebagai salah satu penyuplai unsur hara yang dibutuhkan tanaman dalam proses metabolisme. Cukupnya kebutuhan tanaman akan unsur-unsur pertumbuhan juga merangsang pembentukan daun-daun baru, daun tersebut akan berakibat pada peningkatan luas daun total yang dihasilkan per tanaman (Bilman, 2001).

Tabel 2. Pengaruh Perlakuan Berbagai Jarak Tanam pada Jajar Legowo dan Pemberian Pupuk Organik terhadap Indeks Luas Daun Jagung PERTIWI-3.

\begin{tabular}{|c|c|}
\hline Perlakuan & $\begin{array}{l}\text { Indeks Luas } \\
\text { Daun (ILD) }\end{array}$ \\
\hline 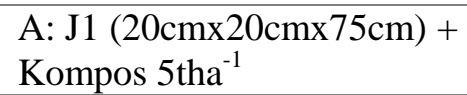 & $2,82 \mathrm{~d}$ \\
\hline 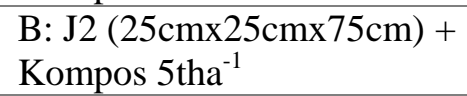 & $2,52 \mathrm{~cd}$ \\
\hline 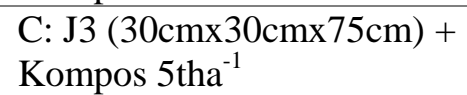 & $1,84 \mathrm{a}$ \\
\hline $\begin{array}{l}\text { D: J1 }(20 \mathrm{~cm} \times 20 \mathrm{~cm} \times 75 \mathrm{~cm})+ \\
\text { Pukan Sapi } 5 \text { tha }^{-1}\end{array}$ & $2,92 \mathrm{~d}$ \\
\hline $\begin{array}{l}\text { E: J2 }(25 \mathrm{~cm} \times 25 \mathrm{~cm} \times 75 \mathrm{~cm})+ \\
\text { Pukan Sapi } 5 \text { tha }^{-1}\end{array}$ & $2,35 \mathrm{bc}$ \\
\hline $\begin{array}{l}\text { F: J3 }(30 \mathrm{cmx} 30 \mathrm{~cm} \times 75 \mathrm{~cm})+ \\
\text { Pukan Sapi } 5 \text { tha }^{-1}\end{array}$ & $1,95 \mathrm{ab}$ \\
\hline $\begin{array}{l}\text { Keterangan:Angka-angka den } \\
\text { yang sama, tidak berbeda ny } \\
\text { Jarak Berganda Duncan pada }\end{array}$ & $\begin{array}{l}\text { notasi huruf } \\
\text { menurut } \mathrm{Uji} \\
\text { nyata } 5 \% \text {. }\end{array}$ \\
\hline
\end{tabular}

\section{Panjang Tongkol dan Diameter}

Tongkol. Berdasarkan hasil uji F, perlakuan jarak tanam dan pupuk organik yang diberikan tidak berpengaruh terhadap komponen hasil panjang tongkol dan diameter tongkol. Terlihat pada Tabel 3, kedua parameter tersebut diikuti dengan notasi huruf yang sama. Panjang tongkol yang diperoleh rata-rata berkisar antara 14,26 $\mathrm{cm}$ hingga $16,10 \mathrm{~cm}$ dan untuk rata-rata diameter tongkol berkisar antara 4,64 cm sampai dengan $4,98 \mathrm{~cm}$.

Diketahui bahwa pertumbuhan, perkembangan dan produksi suatu tanaman ditentukan oleh dua faktor utama yaitu faktor genetik dan faktor lingkungan (Kuyik dkk, 2012). Faktor lingkungan yang dimaksud diantaranya yakni pemberian perlakuan jarak tanam dan penambahan pupuk organik baik 
kompos, maupun pupuk kandang sapi. Menurut Tan (2008) dikutip Wahyudin, et al (2017) tanah dengan nilai $\mathrm{pH}$ yang tinggi memiliki permasalahan yakni rendahnya kandungan $\mathrm{P}$ yang tersedia di tanah karena adanya fiksasi oleh unsur Ca. Salah satu faktor yang mempengaruhi pertumbuhan tongkol jagung (panjang dan diameter) yakni unsur hara $\mathrm{P}$, apabila kekurangan unsur hara ini maka pembentukan tongkol dan biji akan terhambat (Rina, 2015).

Tabel 3. Pengaruh Perlakuan Berbagai Jarak Tanam pada Jajar Legowo dan Pemberian Pupuk Organik terhadap Panjang Tongkol (cm) dan Diameter Tongkol (cm) Jagung PERTIWI-3.

\begin{tabular}{|c|c|c|}
\hline Perlakuan & $\begin{array}{c}\text { Panjang } \\
\text { Tongkol } \\
(\mathrm{cm})\end{array}$ & $\begin{array}{c}\text { Diameter } \\
\text { Tongkol } \\
(\mathrm{cm})\end{array}$ \\
\hline $\begin{array}{l}\text { A: J1 } \\
(20 \mathrm{~cm} \times 20 \mathrm{~cm} \times 75 \mathrm{~cm}) \\
+ \text { Kompos } 5 \text { tha }^{-1}\end{array}$ & $14,26 \mathrm{a}$ & $4,69 \mathrm{a}$ \\
\hline $\begin{array}{l}\text { B: J2 } \\
(25 \mathrm{~cm} \times 25 \mathrm{cmx} 75 \mathrm{~cm}) \\
+ \text { Kompos } 5 \mathrm{tha}^{-1}\end{array}$ & $15,57 \mathrm{a}$ & $4,89 \mathrm{a}$ \\
\hline $\begin{array}{l}\text { C: J3 } \\
(30 \mathrm{~cm} \times 30 \mathrm{~cm} \times 75 \mathrm{~cm}) \\
+ \text { Kompos } 5 \text { tha }^{-1}\end{array}$ & $15,56 \mathrm{a}$ & $4,98 \mathrm{a}$ \\
\hline $\begin{array}{l}\text { D: J1 } \\
(20 \mathrm{~cm} \times 20 \mathrm{cmx} 75 \mathrm{~cm}) \\
+ \text { Pukan Sapi 5tha }{ }^{-1}\end{array}$ & $14,63 \mathrm{a}$ & $4,64 \mathrm{a}$ \\
\hline $\begin{array}{l}\text { E: J2 } \\
(25 \mathrm{~cm} \times 25 \mathrm{~cm} \times 75 \mathrm{~cm}) \\
+ \text { Pukan Sapi 5tha }{ }^{-1}\end{array}$ & $16,10 \mathrm{a}$ & $4,95 \mathrm{a}$ \\
\hline $\begin{array}{l}\text { F: J3 } \\
(30 \mathrm{~cm} \times 30 \mathrm{cmx} 75 \mathrm{~cm}) \\
+ \text { Pukan Sapi 5tha }{ }^{-1}\end{array}$ & $15,72 \mathrm{a}$ & $4,92 \mathrm{a}$ \\
\hline
\end{tabular}

Menurut hasil uji tanah awal laboratorium Fakultas Pertanian Universitas Padjadjaran, nilai $\mathrm{pH}$ yang diperoleh cenderung agak masam sampai netral, sehingga kemungkinan unsur $\mathrm{P}$ terfiksasi oleh kalsium tidak ada. Pemenuhan unsur hara $P$ juga dilakukan yakni dengan pemberian perlakuan pupuk organik ; kompos dengan kandungan $\mathrm{P}_{2} \mathrm{O} 5$ sebesar $1,38 \%$, pupuk kandang sapi dengan kandungan $\mathrm{P}_{2} \mathrm{O} 5$ 0,87\% dan juga pupuk SP-18. Menurut Wahyudin, et al (2017), terserapnya unsur $\mathrm{P}$ menyebabkan fotosintat yang dialokasikan ke tongkol menjadi lebih banyak. Perlakuan jarak tanam $25 \mathrm{~cm} \times 25 \mathrm{~cm} \times 75 \mathrm{~cm}$ ditambah dengan pupuk kandang sapi, memberikan hasil yang lebih baik dibandingkan dengan perlakuan lain dengan panjang tongkol $16,10 \mathrm{~cm}$, sedangkan untuk diameter tongkol perlakuan jarak tanam $30 \mathrm{~cm} \times 30 \mathrm{~cm} \times 75 \mathrm{~cm}$ ditambah kompos menghasilkan diameter lebih baik dari perlakuan lain dengan lingkar tongkol 4,98 cm, namun kedua parameter tersebut tetap tidak berbeda nyata menurut uji statistik.

Jumlah Biji dan Jumlah Baris Biji. Menurut analisis sidik ragam, diperoleh hasil bahwa tidak adanya pengaruh antara perlakuan baik terhadap jumlah biji jagung maupun jumlah baris biji jagung., dapat terlihat dari Tabel 4 . baik rata-rata hasil jumlah biji ataupun ratarata jumlah baris biji jagung diikuti dengan notasi yang tidak berbeda.

Berdasarkan hasil uji (Tabel 4), ratarata jumlah biji jagung per tongkol berkisar antara 373,88 sampai dengan 519,00, walaupun tidak berbeda nyata namun dengan hasil perlakuan jarak tanam $25 \mathrm{~cm} \times 25 \mathrm{~cm} \times 75 \mathrm{~cm}$ ditambah dengan kompos memberikan jumlah biji lebih baik dibandingkan dengan perlakuan lainnya. Hasil pengujian selanjutnya yakni rata-rata jumlah baris biji yang berdasarkan uji F tidak dipengaryhi oleh perlakuan yang diberikan, rata-rata jumlah baris biji jagung yang diperoleh berkisar antara 15,11 sampai dengan 15,82 . Jumlah baris dalam satu tongkol akan mempengaruhi juga jumlah biji dalam satu tongkol tersebut, meskipun baris biji relatif sama namun menurut deskripsi dari jagung PERTIWI-3 hasil tersebut tetap baik, sebab jagung PERTIWI-3 pada umumnya memiliki 14-16 baris dalam satu tongkol. 
Tabel 4. Pengaruh Perlakuan Berbagai Jarak Tanam pada Jajar Legowo dan Pemberian Pupuk Organik Terhadap Jumlah Biji dan Jumlah Baris Biji Jagung PERTIWI-3.

\begin{tabular}{|c|c|c|}
\hline Perlakuan & $\begin{array}{c}\text { Jumlah } \\
\text { Biji }\end{array}$ & $\begin{array}{c}\text { Jumlah } \\
\text { Baris Biji }\end{array}$ \\
\hline 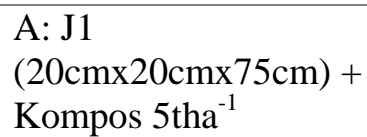 & $373,88 \mathrm{a}$ & $15,11 \mathrm{a}$ \\
\hline 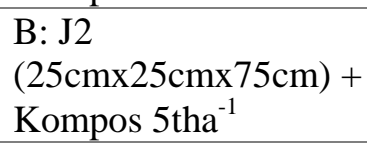 & $519,00 \mathrm{a}$ & $15,82 \mathrm{a}$ \\
\hline $\begin{array}{l}\text { C: J3 } \\
(30 \mathrm{~cm} 330 \mathrm{~cm} \times 75 \mathrm{~cm})+ \\
\text { Kompos } 5 \mathrm{tha}^{-1}\end{array}$ & $456,54 \mathrm{a}$ & $15,70 \mathrm{a}$ \\
\hline $\begin{array}{l}\text { D: J1 } \\
(20 \mathrm{~cm} \times 20 \mathrm{~cm} \times 75 \mathrm{~cm})+ \\
\text { Pukan Sapi } 5 \mathrm{tha}^{-1}\end{array}$ & $400,05 \mathrm{a}$ & $15,27 \mathrm{a}$ \\
\hline $\begin{array}{l}\text { E: J2 } \\
(25 \mathrm{~cm} \times 25 \mathrm{~cm} \times 75 \mathrm{~cm})+ \\
\text { Pukan Sapi } 5 \mathrm{tha}^{-1}\end{array}$ & $455,92 \mathrm{a}$ & $15,39 \mathrm{a}$ \\
\hline $\begin{array}{l}\text { F: J3 } \\
(30 \mathrm{~cm} \times 30 \mathrm{~cm} \times 75 \mathrm{~cm})+ \\
\text { Pukan Sapi } 5 \mathrm{tha}^{-1}\end{array}$ & $433,20 \mathrm{a}$ & $15,45 \mathrm{a}$ \\
\hline
\end{tabular}

Keterangan: Angka-angka dengan notasi huruf yang sama, tidak berpengaruh menurut Uji F dengan taraf nyata $5 \%$.

Menurut Board dan Kahlon (2012), cahaya yang diserap oleh tanaman berpengaruh terhadap proses fotosintesis untuk menghasilkan asimilat yang digunakan sebagai sumber energi pertumbuhan dalam membentuk organ-organ vegetatif fase pertumbuhan, sedangkan pada fase generatif asimilat yang disimpan pada jaringan organ-organ vegetatif akan diremobilisasi dalam pembentukan organ reproduktif, seperti jumlah biji pada tongkol. Seperti diketahui, seluruh pertanaman jagung menerapkan sistem tanam legowo, dimaksudkan agar pertanaman memaksimalkan serapan cahaya matahari.

Nilai jumlah baris biji per tongkol dan jumlah biji per tongkol sangat dipengaruhi oleh faktor lingkungan dan serapan unsur $P$ (Wahyudin et al, 2017). Ketersediaan unsur P pada percobaan ini terbilang cukup, karena selain berasal dari tanah, penambahan pupuk organik baik kompos ataupun pupuk kandang sapi serta penambahan pupuk susulan SP-18, semua sesuai dengan kebutuhan pertanaman jagung. Menurut Wahyudin, et al (2016), namun dominannya sifat genetik mengendalikan sifat jumlah baris pada jagung.

Bobot 100 Biji Pipilan Kering. Berdasarkan uji statistik, hasil yang diperoleh yakni terdapat pengaruh perlakuan terhadap bobot 100 biji jagung pipilan yang kadar airnya kurang lebih 14\%. Hasil yang terdapat pada Tabel 5 menunjukkan bahwa rata-rata bobot 100 biji pipilan kering berkisar antara 30,30 g sampai dengan 45,19 g.

Dari hasil Tabel 5 bobot 100 biji pipilan kering tertinggi yakni sebesar 45,19 g berbeda nyata dibandingkan perlakuan lainnya, dengan perlakuan jarak tanam $20 \mathrm{~cm} \times 20 \mathrm{~cm} \times 75 \mathrm{~cm}$ ditambah pupuk kandang sapi, diikuti perlakuan penambahan pupuk kandang sapi dengan jarak tanam $25 \mathrm{~cm} \times 25 \mathrm{~cm} \times 75 \mathrm{~cm}$ dan jarak tanam $30 \mathrm{~cm} \times 30 \mathrm{~cm} \times 75 \mathrm{~cm}$ lebih baik dibanding dengan perlakuan pemberian kompos pada berbagai jarak tanam, meskipun pada dua perlakuan ini tidak berbeda nyata dengan perlakuan $\mathrm{A}, \mathrm{B}$ dan $\mathrm{C}$ secara uji statistik.

Hal ini diungkapkan oleh Badan Penelitian Tanaman Pangan (2011), pemberian pupuk kandang sapi mampu meningkatkan produksi tanaman hingga mencapai 30\%. Pernyataan lain yang mendukung juga dikemukakan oleh Suratmini (2009), dengan pemberian pupuk kandang sapi mampu meningkatkan bobot kering biji jagung, kemudian menurut Hartatik dan Widowati (2006) penggunaan pupuk kandang sapi mampu meningkatkan hasil yang kontinyu pada pertanaman. 
Tabel 5. Pengaruh Perlakuan Berbagai Jarak Tanam pada Jajar Legowo dan Pemberian Pupuk Organik terhadap Bobot 100 Biji Pipilan Kering (g) Jagung PERTIWI-3.

\begin{tabular}{|c|c|}
\hline Perlakuan & $\begin{array}{c}\text { Bobot } 100 \\
\text { Biji Pipilan } \\
\text { Kering (g) }\end{array}$ \\
\hline $\begin{array}{l}\text { A: J1 }(20 \mathrm{~cm} \times 20 \mathrm{~cm} \times 75 \mathrm{~cm})+ \\
\text { Kompos } 5 \mathrm{tha}^{-1}\end{array}$ & $30,75 \mathrm{a}$ \\
\hline $\begin{array}{l}\text { B: J2 }(25 \mathrm{~cm} \times 25 \mathrm{~cm} \times 75 \mathrm{~cm})+ \\
\text { Kompos } 5 \mathrm{tha}^{-1}\end{array}$ & $30,30 \mathrm{a}$ \\
\hline $\begin{array}{l}\text { C: J3 }(30 \mathrm{~cm} \times 30 \mathrm{~cm} \times 75 \mathrm{~cm})+ \\
\text { Kompos } 5 \mathrm{tha}^{-1}\end{array}$ & $31,45 \mathrm{a}$ \\
\hline $\begin{array}{l}\text { D: J1 }(20 \mathrm{~cm} \times 20 \mathrm{~cm} \times 75 \mathrm{~cm})+ \\
\text { Pukan Sapi } 5 \text { tha }^{-1}\end{array}$ & $45,19 \mathrm{~b}$ \\
\hline $\begin{array}{l}\text { E: J2 }(25 \mathrm{~cm} \times 25 \mathrm{~cm} \times 75 \mathrm{~cm})+ \\
\text { Pukan Sapi } 5 \text { tha }^{-1}\end{array}$ & $31,75 \mathrm{a}$ \\
\hline $\begin{array}{l}\text { F: J3 (30cmx30cmx75cm) + } \\
\text { Pukan Sapi 5tha }{ }^{-1}\end{array}$ & $31,53 \mathrm{a}$ \\
\hline
\end{tabular}

Keterangan:Angka-angka dengan notasi huruf yang sama, tidak berbeda nyata menurut Uji Jarak Berganda Duncan pada taraf nyata 5\%.

Menurut Jugerheimer (1976) dikutip Sumarsono (2008), kepadatan populasi tanaman yang tinggi akan meningkatkan indeks luas daun (ILD). Peningkatan indeks luas daun itu sendiri berdampak pada potensi tanaman dalam melakukan fotosintesis. Menurut Rahmi (2012), translokasi fotosintat yang jumlahnya cukup besar menyebabkan pembentukan tongkol dan pengisian biji berlangsung dengan baik dan biji-biji yang terbentuk bernas dengan ukuran yang lebih besar, hal ini juga dipengaruhi oleh semakin baiknya sistem perakaran tanaman untuk menyerap unsur hara.

Bagian dalam biji yang mempengaruhi berat 100 biji yakni endosperm yang merupakan bagian terbesar dari biji berfungsi sebagai tempat menyimpan fotosintat (Kusnadi, 2000). Berdasarkan hasil yang didapat, perlakuan jarak tanam $20 \mathrm{~cm} \times 20 \mathrm{~cm} \times 75 \mathrm{~cm}$ ditambah pemberian pupuk kandang sapi, merupakan perlakuan terbaik guna meningkatkan bobot 100 biji pipilan kering.

\section{Bobot Biji Pipilan Kering per Tanaman dan Bobot Biji Pipilan Kering per Hektar. Hasil} analisis ragam didapati bahwa, tidak adanya pengaruh antara perlakuan terhadap hasil bobot biji pipilan kering per tanaman ataupun terhadap bobot biji pipilan kering per hektar. Hasil rata-rata bobot biji pipilan kering per tanaman berkisar antara $105,35 \mathrm{~g}$ sampai dengan 141,54 g, dengan perlakuan jarak tanam $30 \mathrm{~cm} \times 30 \mathrm{~cm} \times 75 \mathrm{~cm}$ ditambah kompos menghasilkan bobot biji pipilan kering per tanaman sedikit lebih baik dibandingkan dengan perlakuan lainnya, meskipun hasil seluruh perlakuan tidak berbeda nyata.

Hasil pada Tabel 6 menunjukkan bahwa bobot biji pipilan kering per hektar berkisar antara 7,49 t/ha sampai dengan 8,44 t/ha, dengan perlakuan jarak tanam $20 \mathrm{~cm} \times 20 \mathrm{~cm} \times 75 \mathrm{~cm}$ ditambah kompos sedikit lebih baik dibandingkan perlakuan lainnya, meskipun hasil uji untuk bobot biji pipilan kering per hektar tidak berbeda nyata di semua perlakuan. Menurut Seriminawati dan Purwanto (2005), pertumbuhan yang baik ditunjang oleh penyerapan unsur hara yang cukup yang berakibat meningkatnya fotosintat dan akan tersimpan dalam jaringan penyimpanan sehingga mempengaruhi perkembangan dan pertumbuhan bagian tanaman yang akhirnya akan meningkatkan hasil jagung secara nyata.

Menurut deskripsi, jagung PERTIWI-3 memiliki potensi hasil hingga 13,74 t/ha pipilan kering dengan hasil rata-rata 9,64 t/ha pipilan kering, sedangkan hasil yang diperoleh masih di bawah dari hasil rata-rata jagung PERTIWI-3. Hasil yang kurang maksimal tersebut dapat terjadi karena beberapa faktor, menurut Islami dan Utomo (1995) dikutip Rejekiningrum dan Budi (2015) kurangnya kebutuhan air akan menyebabkan terjadinya cekaman, sehingga berdampak pada pertumbuhan dan hasil. 
Tabel 6. Pengaruh Perlakuan Berbagai Jarak Tanam pada Jajar Legowo dan Pemberian Pupuk Organik terhadap Bobot Biji Pipilan Kering per tanaman (g) dan Bobot Biji Pipilan Kering per Hektar (t/ha) Jagung PERTIWI-3.

\begin{tabular}{ccc}
\hline Perlakuan & Bobot Biji & Bobot Biji \\
Pipilan & Pipilan \\
Kering per & Kering per \\
& Tanaman $(\mathrm{g})$ & Hektar $\left(\right.$ tha $\left.^{-1}\right)$
\end{tabular}

\begin{tabular}{|c|c|c|}
\hline $\begin{array}{l}\text { A: J1 } \\
(20 \mathrm{~cm} \times 20 \mathrm{cmx} 75 \mathrm{~cm}) \\
+ \text { Kompos } 5 \mathrm{tha}^{-1}\end{array}$ & $111,55 \mathrm{a}$ & $8,44 \mathrm{a}$ \\
\hline 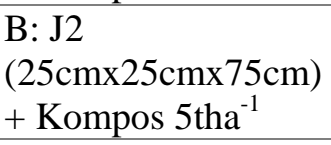 & $105,35 \mathrm{a}$ & $8,26 \mathrm{a}$ \\
\hline $\begin{array}{l}\text { C: J3 } \\
(30 \mathrm{~cm} \times 30 \mathrm{cmx} 75 \mathrm{~cm}) \\
+ \text { Kompos } 5 \mathrm{tha}^{-1}\end{array}$ & $141,54 \mathrm{a}$ & $7,68 \mathrm{a}$ \\
\hline $\begin{array}{l}\text { D: J1 } \\
(20 \mathrm{~cm} x 20 \mathrm{cmx} 75 \mathrm{~cm}) \\
+ \text { Pukan Sapi } 5 \mathrm{tha}^{-1}\end{array}$ & $114,18 \mathrm{a}$ & $8,12 \mathrm{a}$ \\
\hline $\begin{array}{l}\text { E: J2 } \\
(25 \mathrm{~cm} \times 25 \mathrm{~cm} 75 \mathrm{~cm}) \\
+ \text { Pukan Sapi } 5 \mathrm{tha}^{-1}\end{array}$ & $135,85 \mathrm{a}$ & $7,88 \mathrm{a}$ \\
\hline $\begin{array}{l}\text { F: J3 } \\
(30 \mathrm{~cm} \times 30 \mathrm{cmx} 75 \mathrm{~cm}) \\
+ \text { Pukan Sapi } 5 \mathrm{tha}^{-1}\end{array}$ & $131,95 \mathrm{a}$ & $7,49 \mathrm{a}$ \\
\hline
\end{tabular}

Keterangan: Angka-angka dengan notasi huruf yang sama, tidak berpengaruh menurut Uji F dengan taraf nyata $5 \%$.

Rejekiningrum dan Budi (2015) menyebutkan juga bahwa penurunan hasil dapat terjadi apabila tanaman jagung mengalami kekurangan air pada saat fase pembungaan. Menurut Pusat Pelatihan Pertanian (2015), ketepatan pemberian air sesuai tingkat pertumbuhan tanaman jagung sangat berpengaruh terhadap produksi, periode pertumbuhan tanaman jagung yang membutuhkan pengairan salah satunya yakni pada fase pembungaan (15-20 hari). Berdasarkan hasil pengamatan di lapangan, pertanaman jagung yang dicobakan mengalami fase pembungaan pada saat tanaman jagung berumur 55 HST.
Menurut hasil pengamatan Stasiun Klimatologi Ciparanje, diketahui bahwa pada saat pertanaman jagung mengalami fase pembungaan (55 hari setelah tanam), pada lahan percobaan kebutuhan akan air tidak terpenuhi. Terhitung sejak fase pembungaan tanggal 30 Januari 2017 sampai dengan 18 Februari 2017 (20 hari), curah hujan berkisar antara $0 \mathrm{~mm}$ sampai dengan $10 \mathrm{~mm}$, dengan curah hujan rata-rata $2,85 \mathrm{~mm} /$ hari. Menurut Faridah (2003), kebutuhan air pada tanaman jagung yakni dapat mencapai 7,22 mm/hari. Dilihat dari perbandingan tersebut, maka pertanaman jagung yang dicobakan mengalami cekaman yang berakibat terganggunya hasil tanaman jagung.

Indeks Panen. Hasil analisis sidik ragam menunjukkan bahwa tidak adanya pengaruh antara semua perlakuan terhadap indeks panen pertanaman jagung. Indeks panen rata-rata yang didapat yakni berkisar antara 0,33 sampai dengan 0,38 (Tabel 7). Menurut Suhendar (2011), nilai indeks panen untuk tanaman jagung pada daerah tropis sekitar 0,39.

Indeks panen menunjukkan besarnya fotosintat yang tersalurkan untuk pembentukan biji, semakin tinggi indeks panen tanaman jagung maka fotosintat pada tajuk banyak ditranslokasikan ke bagian biji (Efendi dan Suwandi, 2010). Menurut Gardner dan Pearce (1991) dikutip Wahyudin,et al (2017) indeks panen merupakan suatu gambaran hasil asimilat yang diperoleh tanaman. Berdasarkan hasil bobot biji pipilan kering, bobot biji pipilan kering yang didapat tidak berbeda nyata di semua pelakuan, sehingga berpengaruh sama terhadap indeks panen tersebut. Bobot biji pipilan kering merupakan salah satu komponen yang mempengaruhi hasil dari indeks panen (Mungara dan Rogomulyo, 2013) 
Tabel 7. Pengaruh Perlakuan Berbagai Jarak Tanam pada Jajar Legowo dan Pemberian Pupuk Organik terhadap Indeks Panen

\begin{tabular}{|c|c|}
\hline Perlakuan & $\begin{array}{l}\text { Indeks } \\
\text { Panen }\end{array}$ \\
\hline $\begin{array}{l}\text { A: J1 }(20 \mathrm{cmx} 20 \mathrm{cmx} 75 \mathrm{~cm})+\text { Kompos } \\
\text { 5tha }\end{array}$ & $0,34 \mathrm{a}$ \\
\hline $\begin{array}{l}\text { B: J2 }(25 \mathrm{~cm} \times 25 \mathrm{~cm} \times 75 \mathrm{~cm})+\text { Kompos } \\
5 \text { tha }^{-1}\end{array}$ & $0,37 \mathrm{a}$ \\
\hline $\begin{array}{l}\text { C: J3 }(30 \mathrm{~cm} \times 30 \mathrm{~cm} \times 75 \mathrm{~cm})+\text { Kompos } \\
\text { 5tha-1 }\end{array}$ & $0,38 \mathrm{a}$ \\
\hline $\begin{array}{l}\text { D: J1 }(20 \mathrm{cmx} 20 \mathrm{cmx} 75 \mathrm{~cm})+\text { Pukan } \\
\text { Sapi 5tha }\end{array}$ & $0,33 \mathrm{a}$ \\
\hline $\begin{array}{l}\text { E: J2 }(25 \mathrm{~cm} \times 25 \mathrm{~cm} \times 75 \mathrm{~cm})+\text { Pukan Sapi } \\
5 \text { tha }^{-1}\end{array}$ & $0,37 \mathrm{a}$ \\
\hline $\begin{array}{l}\text { F: J3 }(30 \mathrm{~cm} \times 30 \mathrm{~cm} \times 75 \mathrm{~cm})+\text { Pukan Sapi } \\
\text { 5tha }\end{array}$ & $0,36 \mathrm{a}$ \\
\hline $\begin{array}{l}\text { Keterangan: Angka-angka dengan notasi } \\
\text { yang sama, tidak berpengaruh menurut } \\
\text { dengan taraf nyata } 5 \% \text {. }\end{array}$ & $\begin{array}{l}\text { luruf } \\
\text { Jji } F\end{array}$ \\
\hline
\end{tabular}

\section{KESIMPULAN}

Berdasarkan hasil penelitian, dapat diambil simpulan sebagai berikut :

1. Perlakuan jarak tanam pada sistem legowo dengan pemberian pupuk organik tidak berpengaruh terhadap semua pengamatan tinggi tanaman jagung, panjang tongkol, diameter tongkol, jumlah biji, jumlah baris biji, bobot biji pipilan kering per tanaman, bobot biji pipilan kering per hektar dan Indeks Panen (IP) jagung PERTIWI-3 di Jatinangor. Perlakuan jarak tanam pada sistem legowo dengan pemberian pupuk organik hanya berpengaruh terhadap Indeks Luas Daun (ILD) dan bobot 100 biji pipilan kering jagung PERTIWI-3 di Jatinangor.

2. Perlakuan jarak tanam $20 \mathrm{~cm} \times 20 \mathrm{~cm} \times 75 \mathrm{~cm}$ dengan sistem legowo ditambah pemberian kompos pada varietas jagung PERTIWI-3 menghasilkan nilai Indeks Luas Daun (ILD) tertinggi. Pada perlakuan jarak tanam $20 \mathrm{~cm} \times 20 \mathrm{~cm} \times 75 \mathrm{~cm}$ dengan sistem legowo ditambah pemberian pupuk kandang sapi memberikan hasil tertinggi terhadap bobot 100 biji pipilan kering jagung PERTIWI-3 di Jatinangor.

\section{DAFTAR PUSTAKA}

Abdulrachman, Sarlan., Made Jana Mejaya., Nurwulan Agustiani., Indra Gunawan., Priatna Sasmita., dan Agus Guswara. 2013. Sistem Tanam Legowo. Sukamandi : Balai Penelitian dan Pengembangan Pertanian.

Adimihardja, A., I. Juarsah, dan U. Kurnia. 2000. Pengaruh penggunaan berbagai jenis dan takaran pupuk kandang terhadap produktivitas tanah Ultisol terdegradasi di Desa Batin, Jambi. Hlm. 303-319 dalam Pros. Seminar Nasional Sumber Daya Tanah , Iklim, dan Pupuk. Buku II. Lido-Bogor , 6-8 Des.1999. Pusat Penelitian Tanah dan Agroklimat, Bogor.

Akil, M.,dan Hadijah A. Dahlan. 2007. Budidaya Jagung dan Diseminasi Teknologi. Maros : . Balai Penelitian Tanaman Serealia.

Badan Penelitian Tanaman Pangan. 2011. Nilai Tambah Kompos dari Kotoran Sapi. Nusa Tenggara Barat : Badan Penelitian dan Pengembangan Pertanian.

Badan Pusat Statistik. 2015. Produksi Padi, Jagung,Kedelai pada Tahun 2015. Jakarta. Badan Pusat Statistik Indoneisa.

Badan Pusat Statistik. 2016. Luas Panen Jagung Menurut Provinsi (ha). Jakarta : Badan Pusat Statistik Indonesia.

Balai Pengkaji Teknologi Pertanian. 2015. Beberapa Penyakit Pada Tanaman Jagung dan Pengendaliannya. Aceh : Badan Penelitian dan Pengembangan Pertanian.

Bara, Aria., dan M.A. Chozin. 2009. Pengaruh Dosis Pupuk Kandang dan Pemberian Pupuk Uea Terhadap Pertumbuhan dan Produksi Jagung (Zea mays L.) di Lahan Kering. Bogor : Institut Pertanian Bogor.

Bilman, W.S. 2001. Analisis Pertumbuhan Tanaman Jagung Manis (Zea mays saccharata)Pergeseran Komposisi Gulma pada Beberapa Jarak Tanam. 
Jurnal Ilmu-Ilmu Pertanian Indonesia Vol. 3 No. 1, hal 25-30.

Board, J. E., dan Kahlon C.S. 2012. Contribution of Remobilized Total Dry Matter to Soybean Yield. Journal of Crop Improvement Vol. 26, Issue 5, pages 641-654.

Bunyamin Z dan Awaluddin. 2013. Pengaruh Populasi Tanaman terhadap Pertumbuhan dan Produksi Jagung Semi/Baby Corn. Balai Penelitian Tanaman Serelia. Fakultas Pertanian Universitas Hassanudin, Makasar. 233 halaman.

Desyanto, Eky., dan Herman Budi Susetyo. 2014. Pengaruh Jarak Tanam terhadap Pertumbuhan Hijauan dan Hasil Buah Jagung (Zea mays L.) pada Varietas BISI dan PIONEER di Lahan Marginal. Yogyakarta : Universitas PGRI.

Dinariani., Y.B., Suwarsono Heddy., dan Bambang Guritno. 2014. Kajian Penambahan pupuk kandang kambing dan kerapatan tanaman yang berbeda pada pertumbuhan dan hasil tanaman jagung manis (Zea mayssaccharata Sturt). Malang. Jurusan Budidaya Pertanian Fakultas Pertanian Universitas Brawijaya.

Efendi, Roy., dan Suwandi. 2010. Respon Tanaman Jagung Hibrida terhadap Tingkat Takaran Pemberian Nitrogen dan Kepadatan Populasi. Prosiding Pekan Serealia Nasional.

Faridah, Sitti Nur. 2003. Analisis Kebutuhan Air Tanaman Jagung (Zea mays L.)Pada Berbagai Umur Tanam. Makassar : Universitas Hasanuddin.

Hartatik, Wiwik., dan L.R. Widowati. 2006. Pupuk Kandang. Bogor : Balai Penelitian Tanah.

Indrayanti, Laelani Asro. 2010. Pengaruh Jarak Tanam dan Jumlah Benih terhadap Pertumbuhan Vegetatif Jagung Muda. Fakultas Pertanian Universitas PGRI Palangka Raya. Media Sains,Vol. 2, No 2.

Kasryno, Faisal., Effendi Pasandaran., Suyamto., dan Adnyana Made O. 2007. Gambaran umum ekonomi jagung Indonesia. Jakarta. Badan Penelitian dan Pengembangan Pertanian.

Kusnadi, M.H. 2000. Kamus Istilah Pertanian. Penerbit: Kanisius. Yogyakarta.

Kuyik, Antonius R., Pemmy Tumewu., D. M. F. Sumampow., dan E. G. Tulungen. 2012. Respons Tanaman Jagung (Zea mays saccharata L.) terhadap Pemberian Pupuk Organik. Faperta Univ. Sam Ratulangi. Manado.

Mayadewi, Ni Nyoman Ari. 2007. Pengaruh jenis pupuk kandang dan jarak tanam terhadap pertumbuhan gulma dan hasil jagung manis. Denpasar. Fakultas Pertanian Universitas Udayana.

Mujisihono, R., dan T. Santosa. 2001. Sistem Budidaya Teknologi Tanam Benih Langsung (TABELA) dan Jajar Legowo (TAJARWO). Makalah Seminar Perekayasaan Sistem Produksi Komoditas Padi dan Palawija. Diperta Provinsi D.I. Yogyakarta.

Mungara, E.D. Indradewa., dan R. Rogomulyo. 2013. Analisis Pertumbuhan dan Hasil Padi Sawah (Oryza sativa L.) pada Sistem Pertanian Konvensional Transisi Organik dan Organik. Vegetalika Vol. 2 No. 3:1-12.

Oldeman, L.R., 1975. Agroclimatic map of Java \& Madura. Contr. of Centra Res. Inst. for Food Crops 16/76. Bogor.

Pusat Pelatihan Pertanian. 2015. Pemupukkan Jagung. Badan Penyuluhan dan Pengembangan Sumber Daya Manusia Pertanian. Kementerian Pertanian.

Pusat Pelatihan Pertanian. 2015. Pengairan Tanaman Jagung. Badan Penyuluhan dan Pengembangan Sumber Daya Manusia Pertanian Kementerian Pertanian.

Rahmi, N.M. 2012. Efek Fitohormon PGPR terhadap Pertumbuhan Tanaman Jagung. Agribisnis dan Pengembangan Wilayah 3 (2): 27-35.

Rejekiningrum, Popi., dan Budi Kartiwa. 2015. Upaya Meningkatkan Produksi Tanaman Jagung Menggunakan Teknik Irigasi Otomatis di Lahan Kering Kabupaten Lombok Barat, 
Nusa Tenggara Barat. Bogor : Balai Penelitian Agroklimat dan Hidrologi, Badan Penelitian dan Pengembangan Pertanian.

Rina. 2015. Manfaat Unsur N, P dan K Bagi Tanaman. Kalimantan Timur : Balai Pengkaji Teknologi Pertanian Kementerian Pertanian.

Rogi, Johannes E.X., J.L. Kalangi., Johan A. Rombang., A. Lumingkewas., dan Yulia Paskalina. 2010. Produktivitas Jagung (Zea mays L.) pada Berbagai Tingkat Naungan Tanaman Kelapa (Cocos nucifera L.). Manado : Universitas Sam Ratulangi.

Roidah, Ida Syamsu. 2013. Manfaat penggunaan pupuk organik untuk kesuburan tanah. Tulungagung: Universitas Tulungagung.

Samosir, A. T., Paulus, J. M., Sumampow, D. M., dan Tumbelaka, S. 2015. Pemberian Kompos Jerami Padi terhadap Pertumbuhan dan Produksi Tanaman Jagung Manis (Zea mays L. saccharata Sturt). In COCOS (Vol. 6, No. 12).

Sari, Winda Ismaya., Sisca Fajriani., dan Sudiarso. 2016. Respon Pertumbuhan Tanaman Jagung Manis (Zea mays saccharata Sturt) terhadap Penambahan Berbagai Dosis Pupuk Organik Vermikompos dan Pupuk Anorganik. Jawa Timur : Universitas Brawijaya.

Seriminawati, E. A. Syaifudin., dan H. Purwanto. 2005. Pengaruh Gulma Jawan (Echinochloa cruss-galli L.) terhadap Pertumbuhan dan Produksi Beberapa Kultivar Lokal Padi (Oryza sativa L.) Lahan Kering. Jurnal Budidaya Pertanian 11. 2 September 2005.

Setyamidjaja, D. 2006. Pupuk dan pemupukan. CV. Simpleks, Jakarta.

Stalcup, L. 2008. Twin Rows Help Boost Yields: Stil, The Jury's Out on Whether Twin Rows are Always Profitable. Corn and Soybean Digest;
Jan 2008; 68,1; ABI/Inform Trade and Industry. Pg. 6.

Subiksa, I Gusti Made. 2011. Pengaruh Jarak Tanam dan Jenis Pupuk terhadap Pertumbuhan, Produksi Silase dan Biji Pipilan Jagung Hibrida pada Inceptisol Dramaga. Bogor : Badan Penelitian dan Pengembangan Pertanian.

Suhendar, D. 2011. Pengaruh Dosis Pupuk $\mathrm{N}, \mathrm{P}, \mathrm{K}$ dan Jenis Pupuk Organik terhadap Pertumbuhan dan Hasil Tanaman Jagung (Zea mays L.) Hibrida P-12 di Jatinangor. Sumedang.

Sumarsono. 2008. Model Hubungan Kepadatan Populasi Tanaman terhadap Hasil Tanaman Jagung (Zea mays L.). Semarang : Universitas Diponegoro.

Supartha, I.N.Y., G. Wijana, dan G.M. Adyana. 2012. Aplikasi jenis pupuk organik pada tanaman padi sistem pertanian organik. J. Agroekoteknologi Tropika 1:98- 106.

Tabri, Fahdiana. 2013. Pengaruh Kepadatan Populasi terhadap Hasil Dua Varietas Jagung Hibrida. Maros : Balai Penelitian Tanaman Serealia.

Wahyudin, A., B.N. Fitriatin., F.Y. Wicaksono., Ruminta., dan Rahadiyan. 2017. Respons Tanaman Jagung (Zea mays L.) Akibat Pemberian Pupuk Fosfat dan Waktu Aplikasi Pupuk Hayati Mikroba Pelarut Fosfat pada Ultisols Jatinangor. Jurnal Kultivasi Vol. 16 (1) Maret 2017.

Wahyudin, A., Ruminta., dan D. C. Bachtiar. 2015. Pengaruh Jarak Tanam Berbeda pada Berbagai Dosis Pupuk Organik terhadap Pertumbuhan dan Hasil Jagung Hibrida P-12 di Jatinangor. Jurnal Kultivasi Vol. 14 (1) Maret 2015.

Wahyudin, A., Ruminta., dan S.A. Nursaripah. 2016. Pertumbuhan dan Hasil Tanaman Jagung (Zea mays L.) Toleran Herbisida Akibat Pemberian Berbagai Dosis Herbisida Kalium Glifosat. Jurnal Kultivasi Vol. 15 (2) Agustus 2016. 